French budget

\section{Bleak prospect for researchers}

THE French government research budget for 1987 is now more or less complete. No figures have been released, nor are they likely to be before September, but the indications are that the spending power of French scientists will at best be pegged at around the levels of 1985. There may also be redundancies, as the Prime Minister, Jacques Chirac. has ordered a 1.5 per cent across-the-board cut in government employment. There is hope, however, that the job losses will be partly compensated by a growth in the recruitment of young scientists, under a government scheme to counter youth unemployment.

The worsening prospects for French scientists, coming after the boom years of the early $1980 \mathrm{~s}$, were heralded by an 8 per cent cut in the science budget made in April, just a month after the new government came to power. The change shows

\section{Terrorists strike again Hamburg}

The terror against technology in West Germany continues. Following the killing of Siemens research manager Karl Heinz Beckurts by terrorists of the Rote Armee Fraktion (RAF), a bomb exploded at the Fraunhofer Institute for Laser Research in Aachen at $5 \mathrm{a} . \mathrm{m}$. on Thursday last week. The total damage has not yet been estimated, but some sensitive machines seem to have been affected. In a letter found near the site, a "Fighting force Sheban Atlouf' admitted its responsibility for the attack. The institute, which is part of the Technical University of Aachen, is carrying out research only on the introduction and use of laser techniques for industrial and medical purposes, according to the head of the institute, Professor Herziger.

RAF struck again last Friday at 5 a.m. This time their chosen target was more in line with their announced aim of hitting military and nuclear research institutes. The bomb exploded outside the headquarters of Dornier $\mathrm{GmbH}$, owned by Daimler Benz, in Immenstaad. Only a wall and about 250 windows were damaged.

Police think that this may be the beginning of a series of bombings against what RAF calls the "Militärisch Industrieller Komplex". Last year, when some bombs exploded near institutes for biotechnology and gene research, the new aim of the terrorists became clear. In the underground newspaper Sabot, anonymous sources have announced that "harmless" people in various institutes will face assassination. Protection for such a wide range of imperilled people and institutes cannot be given. Scientists have a hard challenge to face.

Jurgen Neffe how depressingly shallow-rooted was the science policy-making system instituted by the previous administration during its five years in power. Research, it seems, never became a proper political and administrative fiefdom, and now the parts of the old estate, the ministry of research and technology, have been scattered among the ministries from which they were first confiscated in 1981 .

The result, according to one senior French scientist, is that there can no longer be a science policy in France. Rather, research will get the scraps of the budget that are left after the real political carnivores - the ministers responsible for police and defence, among others, in this government - have torn at it. Only then will the minister of research and higher education, the well-meaning physicist Alain Devaquet, have a chance to form a policy. The importance for research and technology of having a politically powerful champion (in the previous French government it was Jean-Pierre Chevènement, who led the largest single wing of the socialist party) has never been clearer. Without power, the budget determines the policy; with it, the reverse is possible.

The Conseil Supérieur de la Recherche et de la Technologie (CSRT), the independent group of high-level scientific advisers to Devaquet, is already well aware of the sea-change facing French science, but seems powerless to act. Having seen the outline budget for 1987 . the Conseil has been forbidden by Devaquet to speak of it. The minister will present his budget, which given inflation and the April cuts would need a 6 per cent increase in current francs to retain the spending power of 1985, probably in September. Only then will CSRT, of which Devaquet is ex-officio chairman, be free to publish its "advice".

Nevertheless, François Kourilsky, the Marseilles immunologist and scientific president of CSRT, has dared to warn that any suppression of scientific jobs would have "long-term effects incommensurate with the economies achieved", and to demand that the government "finish and publish a research and technology policy". This may come with Devaquet's awaited presentation, but the feeling is now clear in France that science has returned to the doldrums of the $1970 \mathrm{~s}$. Then, ministers in the Délégation Générale à la Recherche Scientifique et Technique (DGRST) who were responsible for "coordinating" the research budget in the prime minister's office were renowned for their fine forward-looking speeches in the Assemblée Nationale - - but for their almost total lack of power to influence real events.
US-Japan trade No easy end to
chip war

Washington

AN agreement is expected early this week in the long and increasingly bitter negotiations between Japan and the United States on semiconductor trade. The United States is seeking greater access to Japanese markets for US semiconductor manufacturers, and an end to "dumping" of Japanese semiconductors on international markets. As both legal and self-imposed deadlines loom, negotiations have entered what a spokesman for the US semiconductor industry termed "a period of trench warfare"

For more than a year, the US semiconductor industry has been pursuing a trade complaint against Japan over access to Japanese semiconductor markets. US chips now account for only 10 per cent of sales in Japan according to US industry figures, as opposed to 83 per cent of sales in the United States and 55 per cent of sales in Europe. In late May, US Trade Representative Clayton Yeutter worked out a framework for concluding the trade case, known as the 301 case after the section of the Trade Act of 1974 that covers unfair trade practices. Included in the framework is the resolution of two other complaints that Japanese companies are selling erasable programmable read-only memory chips (EPROMs) and 256 kilobyte dynamic random access memory chips (256K DRAMs) below their production costs. A preliminary judgement made last year by the Department of Commerce found Japanese companies guilty of dumping in violation of international trade agreements. But in early July, both sides reached a tentative agreement to drop the dumping cases so that negotiations in a comprehensive agreement could continue. Since June, US and Japanese negotiators have been trying to forge an agreement under Yeutter's framework, but so far without success. Without a final decision to stop the dumping cases this week, permanent dumping duties will be imposed on all imported Japanese EPROMs and 256K DRAMs.

Opening Japanese markets to US goods is not straightforward. Despite the power of the Japanese Ministry of International Trade and Industry, it cannot force Japanese companies to buy US chips. The Japanese government has offered to open a special office to assist foreign companies in making semiconductor sales.

Japanese semiconductor producers are large, vertically integrated companies that can subsidize losses in their semiconductor division to purchase market share, an option not open to generally smaller US firms. No agreement will 
change this situation.

A document leaked to the Financial Times of London gave details of a working draft of the agreement. The United States would agree to drop its dumping cases, and Japan would try to increase US market share in semiconductors to 20 per cent. To prevent future dumping disagreements, the United States would request

WrrH a self-imposed deadline of Saturday, 26 July for concluding the negotiations, Japanese representatives were no doubt surprised when the US team announced on Friday that negotiations had to stop at 1 p.m. The reason? The Trade Representative's office had scheduled its annual picnic for that day, and not even Washington's current heat wave was going to stop plans for a softball game during the picnic.

immediate consultations between the two governments. These consultations would be limited to 14 days, in contrast to the year it now takes to resolve dumping issues. If dumping is suspected, the Japanese government will encourage its industry to provide documentation for the legitimacy of its sales figures.

Even if an agreement is reached, chip prices in Japan will probably stay comparatively low, and US importers are likely to find "loopholes" - purchasing semifinished goods containing chips or buying chips at Tokyo discount stores. Nevertheless, Japanese companies do appear to be worried by the agreement. They find it blatantly unfair and one-sided, placing Japan at a disadvantage to South Korea, Taiwan and especially to US companies that will have access to Japanese production costs under anti-dumping agreements. Japanese industry sees this agreement as being largely beyond their control, having arisen out of the politically close relationship between President Reagan and Prime Minister Nakasone.

As talks moved into the eleventh hour, both sides seemed intransigent. Three US manufacturers complained formally to the Department of Commerce that Japanese companies were trying to cut last minute deals at bargain prices with US customers before signing an agreement. By 30 July a decision has to be made on the EPROM dumping case, and the next day President Reagan must announce what action he will take in the 301 trade case. As Nature goes to press, it is impossible to say what the likely outcome would be.

The US industry is frustrated by the current negotiations. It believes it has an open and shut case against the Japanese both for dumping and for closing their markets. Hopes for agreement may have given way to a desire for retaliation against Japan for its trade practices. But a comprehensive agreement is still the ultimate goal. At stake could be nothing short of the future of the US semiconductor industry. Joseph Palca \& David Swinbanks

High-technology trade

\section{Anger over supercomputer veto}

Ufficials at the British Embassy in Washington hope that they can soon resolve "without major compromise" the difficulties of British academics in obtaining US-manufactured supercomputers. Intensive discussions have been taking place over an issue that last week sparked a debate in the House of Commons.

The trouble began when the University of London Computer Centre found that its purchase of a Cray I supercomputer had been blocked by US government regulations. A condition of sale of the supercomputer is that scientists from Eastern Bloc countries and China must not gain access to the machine. But the centre's director, Richard Field, says that although the scientific standards of work carried out on the machine will be monitored, it is not possible to police all the computer's users to ensure there are no scientists from proscribed countries among them.

What has really enraged British opposition politicians is that the computer the centre wants is second-hand and already in Britain; all that has been requested is its transfer from the Atomic Energy Authority's Harwell laboratory. That the United States can control the movement of a computer inside Britain is described by Liberal Member of Parliament $\mathrm{Mr}$ Paddy Ashdown, who initiated the House of Commons debate, as a "flagrant breach of British sovereignty". And it became clear during the debate that while this may be the first time US controls have hit academics, British high-technology companies have had difficulties with US government regulations for some time. Indeed, Ashdown claims that one British company was effectively driven out of business by US sanctions.

The US regulations come on top of the COCOM agreement that regulates the export of strategically sensitive goods from members of the North Atlantic Treaty Organisation and Japan. British companies that wish to export manufactured goods containing any US component (as do most electronic products) now find themselves having to apply for a licence from both the UK Department of Industry and the US Department of Commerce.

Ashdown's exhortations to take on the United States did not go down well with the government. The official response: from Minister of Information Technology Mr Geoffrey Pattie, was that "if we could compel the United States to withdraw

the problem could be eliminated easily. but we cannot ... and US reaction to a direct and comprehensive challenge cannot be predicted". Rather than accept the opposition view of British Prime Mini- ster Margaret Thatcher's "craven subservience to President Reagan“. Pattie dwelt on the overall advantages to Britain of commercial and scientific links with the United States - plus the new efforts to reduce that dependence by strengthening links with Europe in large-scale development programmes. Problems with the United States have to be dealt with by a "case-by-case" approach. he says.

This view is scarcely welcome to British Embassy officials in Washington who have to do the case-by-cáse negotiations and hope for a more general understanding. An agreement is needed soon if research at the University of London is not to be severely disrupted. The computer should be delivered next month according to the contract, on which a prepayment has already been made. If the computer is not in place by the end of the year. the contract will be void and the computer centre will have to do what it can to seek redress. Any decision will also have a bearing on a contract for delivery of a Cray to the Science and Engineering Research council's Rutherford Appleton Laboratory next year.

Alun Anderson

\section{Science Digest dies Washington}

SCIENCE Digest last week became the latest casualty of the turmoil hitting popular science magazines. Hearst Magazines, its publisher, announced that the September issue of Science Digest will be the last. The subscription list and licensing rights to the name have been bought by Time Inc., publisher of Discover, for an undisclosed sum.

The announcement came as a shock to editorial staff, who have been given a week to clear out their desks. Hearst had been trying unsuccessfully to sell the magazine for several months before finally deciding to cease publication, mainly because of a drastic fall in advertising revenues (see Nature 322. 99; 1986). Hearst expects to retain and reassign about a third of the $\mathbf{2 6}$ Science Digest staff.

Time Inc. also recently bought for $\$ 6$ million the logo and subscription list of Science 86 , the popular science magazine published until last month by the American Association for the Advancement of Science; its readers will be offered Discover instead. Science Digest subscribers will be offered a choice of various Time publications. A spokesman for Time Inc. said that Hearst had already made the decision to cease publication of Science Digest before Time agreed to buy the subscription list: the Science Digest logo is not likely to be used.

Tim Beardsley 